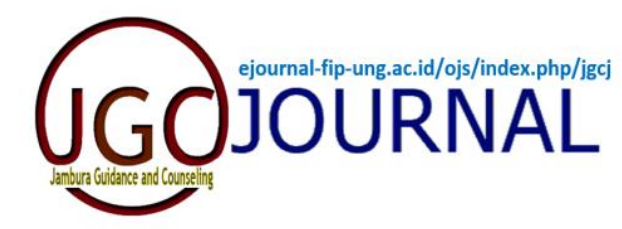

Jambura Guidance and Counseling Journal Volume 2 Nomor 1 (Mei 2021), halaman 1-9

ISSN Online 2722-1628

\title{
Analisis Nilai-nilai Karakter dalam Adat Aqiqah di Gorontalo
}

\author{
Abdul Kadir Tangahu1, Tuti Wantu², Meiske Puluhulawa ${ }^{3}$ \\ Jurusan Bimbingan dan Konseling, Fakultas Ilmu Pendidikan, Universitas Negeri Gorontalo, Indonesia ${ }^{1,2,3}$ \\ abdulkadirtangahu@gmail.com
}

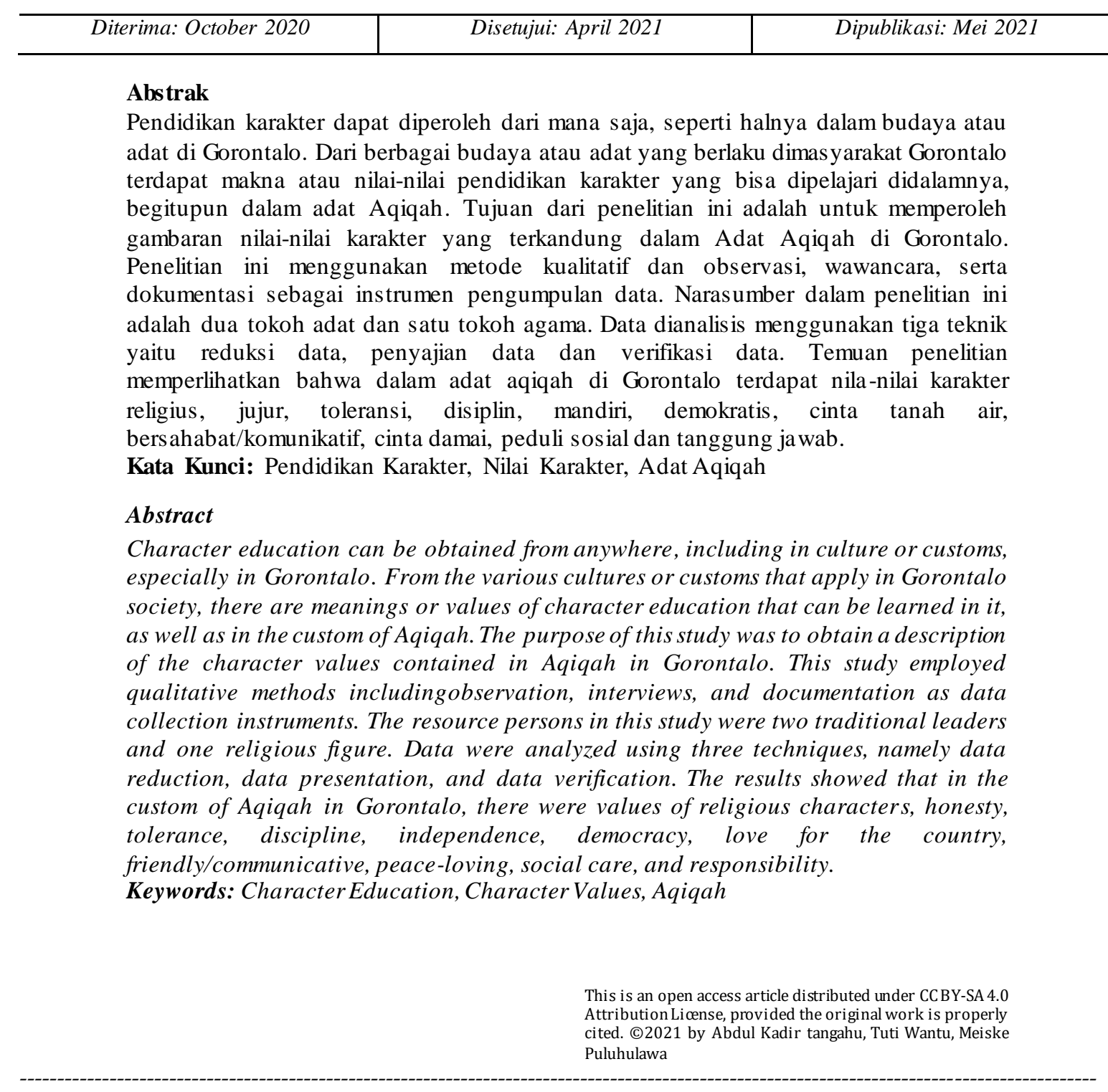

\section{PENDAHULUAN}

Pendidikan nasional merupakan rumusan mengenai kualitas manusia Indonesia yang harus dikembangkan oleh setiap satuan pendidikan. Oleh karena itu, rumusan pendidikan nasional menjadi dasar dalam pengembangan pendidikan budaya dan karakter bangsa. Menurut Kemendiknas (dalam Wibowo 2013: 10) karakter adalah watak, tabiat, akhlak, atau kepribadian seseorang yang terbentuk dari hasil 
internalisasi berbagai kebajikan (virtues), yang diyakini dan digunakan sebagai landasan untuk cara pandang berpikir, bersikap, dan bertindak.

Pendidikan di dapat tidak hanya melalui pendidikan formal saja, pendidikan juga dapat diperoleh melalui pendidikan nonformal seperti pendidikan dari orang tua dan masyarakat. Masyarakat sebagai lingkungan pendidikan yang lebih luas dalam terselenggaranya proses pendidikan karakter. Setiap individu masyarakat harus bertanggung jawab dalam menciptakan suasana yang nyaman dan mendukung tumbuh kembangnya karakter individu-individu di masyarakat. Oleh karena itu, sepantasnya masyarakat yang baik dapat melahirkan berbagai kegiatan kemasyarakatan yang mendukung tumbuh kembangnya karakter, seperti peringatan hari besar keagamaan di masjid, taman pengajian Al-Quran dan pelaksanaan ritual budaya tertentu dalam lingkungan tersebut. Hal yang paling dekat yang dapat dijumpai dalam masyarakat yaitu pelaksanaan budaya serta peraturan adat istiadat yang berlaku dalam suatu daerah, secara langsung mengatur tata kelola kehidupan serta kepribadian masyarakat yang tinggal didaerah tersebut dan juga memuat unsur-unsur kebaikan dalam pengembangan karakter positif setiap individu sebagai anggota masyarakat.

Berangkat dari fenomena seperti ini maka peran segala pelaku pendidikan sangat diperlukan untuk mengenalkan tentang nilai kepribadian, yakni nilai pendidikan karakter yang dapat dipelajari dari adat kebudayan masing-masing daerah. Dalam situasi seperti inilah peran bimbingan dan konseling yang bertugas memantau perkembangan peserta didik baik di lingkungan sekolah maupun masyarakat akan terasa diperlukan sebagai suatu bentuk bantuan kepada individu atau peserta didik dalam mempelajari nilai-nilai karakter yang terdapat dalam pelaksanaan adat budaya di daerahnya.

Berangkat dari fenomena seperti ini maka peran segala pelaku pendidikan sangat diperlukan untuk mengenalkan tentang nilai kepribadian, yakni nilai pendidikan karakter yang dapat dipelajari dari adat kebudayan masing-masing daerah. Dalam situasi seperti inilah peran bimbingan dan konseling yang bertugas memantau perkembangan peserta didik baik di lingkungan sekolah maupun masyarakat akan terasa diperlukan sebagai suatu bentuk bantuan kepada individu atau peserta didik dalam mempelajari nilai-nilai karakter yang terdapat dalam pelaksanaan adat budaya di daerahnya.

Salah satu kearifan budaya lokal yang masih terjaga saat ini yaitu budaya Aqiqah. Aqiqah yaitu peristiwa penyembelihan binatang (kambing) pada hari mencukur rambut anak yang baru dilahirkan. Disunatkan mencukur rambut anak laki-laki maupun perempuan pada hari ketujuh dari hari lahirnya, setelah aqiqah disembelih Aqiqah merupakan ajaran agama islam yang di contohkan oleh Rasulullah SAW dan merupakan salah satu bentuk praktek ritual keagamanan islam yang sangat kental di Indonesia selain ritual keagamaan lainnya seperti sholat, qurban, haji dan ibadah lainnya. Aqiqah cukup populer di Indonesia, dan aqiqah dipandang sebagai ritual keagamaan yang akan mendapat pahala dan berkah yang besar baik itu untuk sang bayi maupun orang tuanya.

Menurut Asrori (1998: 88) dalam sejarahnya, aqiqah termasuk salah satu dari ritual orang Arab pra-islam yang dilaksanakanan dengan menyembelih kambing yang 
pada saat kelahiran anak laki-laki mereka kemudian darah sembelihan dioleskan ke kepala si bayi. Dengan datangnya syariat islam, praktek tersebut diubah, menyembelih kambing dan memotong rambut kepala si bayi serta bayi tersebut dibubuhi dengan minyak zafaran. Perubahan lain adalah apabila masa Jahilliyah hanya diperuntukan bagi bayi laki-laki, tradisi ini pun diubah sehingga bayi perempuan mendapat hak untuk di aqiqah.

Seperti halnya di Indonesia, penduduk mayoritas muslim di indonesia melaksakan ritual ini. Begitupun dengan penduduk muslim Gorontalo yang melaksanakan ritual ini sebagai tanda ungkapan rasa syukur atas kelahiran sang bayi di dunia, dan juga salah satu upaya untuk mendidik anak sejak dini. Dengan harapan, supaya anak menjadi orang yang berbakti kepada orang tua, agama dan negara. Gorontalo merupakan salah satu Provinsi yang ada di Indonesia yang memiliki banyak adat budaya di dalamnya, dan keberagaman adat budaya Gorontalo cukup diperhitungkan di tingkat Nasional. Menurut Botutihe (2003: 4) "Kebudayaan Gorontalo merupakan kebudayaan yang ke sembilan dari sembilan belas kebudayaan di Nusantara. Hal ini ditandai dengan masuknya Islam di Gorontalo membawa dampak implikasi pada berbagai aspek kehidupan masyarakat". Keberadaan adat budaya di daerah ini sangat kental seperti yang terkandung dalam semboyan Adat Gorontalo "Adat hula-hula'a to syareati, syareati hula-hula'a to Kitabullah" yang artinya " Adat bersendikan sara'a, sara'a bersendikan Kitabullah (Al-Qur'an). Sehingga segala macam prosesi yang dilaksanakan dalam kehidupan sosial budaya sehari-hari syarat akan ketentuan adat berlaku.

\section{METODE}

Metode penelitian ini adalah kualitaif dengan pendekatan analisis. Sumber data dalam penelitian ini adalah dua tokoh adat dan satu tokoh agama di Gorontalo. Metode pengumpulan data menggunakan instrumen wawancara dalam mencari data nilai-nilai karakter yang terdapat dalam adat aqiqah di Gorontalo sebagai mana dapat dilihat pada tabel 1 .

Tabel 1. Pedoman Wawancara Nilai-nilai Karakter Dalam Adat Aqiqah

\begin{tabular}{clll}
\hline No & Nilai Karakter & \multicolumn{1}{c}{ Pertanyaan } \\
\hline 1 & Religius & $\begin{array}{l}\text { Apakah dengan melaksanakan adat akikah seseorang dapat } \\
\text { meningkatkan ketakwaannya terhadap Tuhan Yang Maha Esa ? }\end{array}$ \\
2 & Jujur & $\begin{array}{l}\text { Apakah setelah melaksanakan serta mempelajari adat akikah } \\
\text { seseorang dapat meningkatkan upaya untuk menjadikan dirinya }\end{array}$ \\
& & sebagai orang yang dapat dipercaya dalam perkataan, tindakan, \\
& dan pekerjaan ? \\
& Apakah setelah melaksanakan serta mempelajari adat akikah \\
& Toleransi & seseorang dapat meningkatkan upaya untuk menjadikan dirinya \\
& & sebagai orang yang dapat dipercaya dalam perkataan, tindakan, \\
& dan pekerjaan ?
\end{tabular}


4 Disiplin Apakah setelah melaksanakan adat akikah, seseoarang dapat mempelajari bagaimana individu menjadi pribadi yang tidak mudah bergantung pada orang lain ?

5 Mandiri Apakah setelah melaksanakan adat akikah, seseoarang dapat mempelajari bagaimana individu menjadi pribadi yang tidak mudah bergantung pada orang lain ?

6 Demokratis Apakah setelah melaksanakan adat akikah, seseorang dapat mempelajari bagaimana cara berpikir dan bertindak menilai sama hak dan kewajiban dirinya dengan orang lain ?

7 Cinta Tanah Air Apakah dalam pelaksanaan adat akikah seseorang dapat mempelajari bagaimana mencintai negeri sendiri dengan segala keragaman yang ada di dalamnya ?

8 Bersahabat/ Apakah melalui pelaksanaan akikah seseorang dapat Komunikatif mengembangkan perasaan senang bergaul dan bekerja sama dengan orang lain ?

9 Cinta Damai Apakah dengan mempelajari secara mendalam tentang pelaksanaan adat akikah seseorang dapat mengembangkan sikap, perkataan dan tindakan yang menyebabkan orang lain merasa senang dan aman atas kehadiaran dirinya ?

10 Peduli Sosial Apakah dalam pelaksanaan adat akikah seseorang dapat mengembangkan sikap dan tindakan dalam memberi bantuan pada orang atau masyarakat yang membutuhkan ?

11 Tanggung Apakah dengan mempelajari serta mengamalkan nilai-nilai yang Jawab terkandung dalam adat akikah seseorang dapat mengembangkan sikap dan perilaku melaksanakan tugas dan kewajiban yang seharusnya dia lakukan, terhadap diri sendiri, masyarakat serta lingkungan sosial budaya ?

\section{HASIL TEMUAN}

Hipotesis yang menjadi pijakan dalam penelitian ini yaitu "terdapat nilai-nilai karakter dalam pelaksanaan adat aqiqah di Gorontalo". Hipotesis tersebut diuji dengan menggunakan pedoman observasi dan wawancara dalam mengungkap nilai-nilai karakter apa saja yang terdapat dalam adat aqiqah di Gorontalo. Berdasarkan hasil wawancara yang dilakukan terhadap dua orang pemangku adat dan satu tokoh agama dapat disimpulkan bahwa dalam pelaksanaan adat aqiqah di Gorontalo terdapat nilai pendidikan karakter. Berikut hasil temuan dalam penelitian.

\section{Religius}

Berdasarkan hasil penelitian yang dilakukan aqiqah dapat meningkatkan religius seseorang karena melakukan aqiqah termasuk dalam syariat agama Islam dan salah bentuk kepercayaan kita terhadap Nabi Muhammad S.A.W yang tentunya meningkatkan religius bagi setiap orang yang melakukannya. Menurut Kurniawan (2016:205) bahwa tempattempat ibadah dapat menjadi pusat penyemaian nilai-nilai karakter masing-masing individu 
di masyarakat, khususnya nilai-nilai religius. Disamping kegiatan yang sifatnya ritual, juga dapat diselengarakan kegiatan sosial terutama untuk masyarakat sekitar, seperti kunjungan remaja masjid ke panti asuhan, santunan fakir miskin dan anak yatim, santunan massal dan lain-lain.

\section{Jujur}

Berdasarkan hasil penelitian maka dapat disimpulkan pelaksanaan aqiqah terdapat sebuah pembelajaran untuk selalu berperilaku jujur, hal tersebut terlihat melalui sejarah terjadinya aqiqah, ketika nabi Ibrahim As menjalani perintah Allah SWT untuk menyembelih anaknya nabi Ismail As walaupun itu perintah yang berat baginya. Dari sejarah tersebut maka dapat disimpulkan bahwa aqiqah pada hakekatnya dapat membuat orang dapat dipercaya dalam hal perkataan dan tindakan karena dalam sejarahnya, nabi Ibrahim As patuh dan taat terhadap perintah Allah SWT serta jujur kepada anaknya nabi Ismail As bahwa dia akan disembelih. Menurut Kurniawan (2016:205) jujur dapat dimaknai sebagai kebenaran. Artinya, jika tidak ada kebenaran dalam sebuah berita yang disampaikan seseorang, ia dapat disebut tidak jujur. Jujur juga bermakna keselarasan. Selain jujur dalam ucapan, kejujuran terdapat juga pada perbuatan.

\section{Toleransi}

Melalui pelaksanan aqiqah seseorang dapat mempelajari tentang pentingnya sikap toleransi dengan bermodalkan niat yang tulus untuk berbuat baik kepada sesama. Hal tersebut terlihat melalui cara pembagian daging aqiqah, sepertiga kita makan sepertiga orang mampu dan sepertiga orang tidak mampu. Dari proses tersebut terlihat nilai saling mengahargai antar sesama umat manusia karena merasa semua orang memiliki hak yang sama dalam hal menikmati daging aqiqah. Menurut Kurniawan (2016:206) bahwa peran Tokoh Agama dan Tokoh Masyarakat terutama dalam mensosialisasikan secara terusmenerus kepada warga masyarakat tentang pentingnya mengakui hak setiap orang, menghormati keyakinan orang lain, bersikap lapang dada, menerima perbedaan, saling pengertian, kesadaran dan kejujuran. Kegiatan-kegiatan perayaan hari besar keagamaan atau kegiatan-kegiatan seremonial di masyarakat dapat dimanfaatkan untuk mensosialisasikanhal tersebut.

\section{Disiplin}

berdasarkan hasil penelitian bahwa pelaksanaan adat aqiqah memiliki nilai karakter disiplin karena melakukan aqiqah merupakan bentuk kedisiplinan orang tua dalam menjalankan syariat Islam dan adat Gorontalo. Nilai disiplin lainnya terlihat dari tata cara pelaksanaanya, misalnya dalam waktu melakukan aqiqah, yang telah ditentukan dari anak lahir sampai dia sebelum akhir baliq. Menurut Daryanto (2013: 49) Disiplin pada dasarnya merupakan sebuah kontrol diri untuk mematuhi aturan, baik yang dibuat oleh diri sendiri maupun dari luar dirinya

\section{Mandiri}

Berdasarkan hasil penelitian dapat disimpulkan bahwa nilai karakter mandiri dapat dipelajari melalui adat aqiqah, karena melakukan aqiqah merupakan tanggung jawab setiap orang tua dalam menjalankan syariat Islam dan adat Gorontalo. Dari hal tersebut terlihat 
kemandirian setiap orang tua karena sudah menjalankan tanggung jawab sebagai umat agama Islam, sebagai anggota masyarakat adat Gorontalo serta sebagai orang tua..

\section{Demokratis}

Pembelajaran tentang pentingnya sikap demokratis bagaimana menilai sama hak dan kewajiban antar sesama individu melalui makna pelaksanaan aqiqah dapat dilihat dari proses melakukan aqiqah kepada setiap anak baik itu anak pertama sampai anak yang terakhir, serta pemabagian daging aqiqah yang rata baik itu kepada fakir miskin maupun orang mampu. Dari dua hal tersebut terlihat bahwa semua orang memiliki hak yang sama.

\section{Cinta Tanah Air}

Wujud kecintaan itu terlihat dari melakukan aqiqah karena melakukan aqiqah sama saja mengakui atau mencintai adat dan budaya yang ada di negara ini. Dengan melakukan aqiqah kepada anak, maka secara tidak langsung telah melestarikan adat dan budaya ini terus ada. Menurut Kurniawan (2016:211) bahwa mengingat pentingnya rasa cinta tanah air ini, sudah semestinya dapat ditumbuh-kembangkan pada setiap warga masyarakat. Beberapa hal positif yang dapat dikembangkan di lingkungan masyarakat untuk mengembangkan rasa cinta tanah air, diantaranya memperingati hari besar nasional dengan kegiatan lomba atau pentas budaya.

\section{Bersahabat/Komunikatif}

Berdasarkan hasil penelitian dapat disimpulkan bahwa aqiqah memiliki nilai bersahabat/komunikatif. Hal ini terlihat dari proses penerimaan tamu yang tidak membedabedakan dan dilakukan secara bersahabat atau dengan baik. Menurut Kurniawan (2016:212) bahwa gotong royong merupakan warisan budaya nenek moyang dan tradisi positif di trngah masyarakat Indonesia. Budaya gotong royong harus dipelihara dan pertahankan di tengah perkembangan gaya hidup modern dan perkembangan teknologi saat ini, karena dapat menjadi sarana bagi warga untuk saling berinteraksi dan berkomunikasi satu sama lain.

\section{Cinta Damai}

Berdasarkan hasil penelitian dapat dikatakan bahwa pelaksanaan adat aqiqah dapat mengajarkan kepada individu mengembangkan sikap cinta damai antar sesama manusia selaku makhluk sosial. Hal ini terlihat dari sikap penerimaan kepada setiap orang yang datang untuk melihat proses aqiqah yang harus dilakukan dengan baik agar orang yang datang merasa senang dan aman berada di sekitar kita. Melakukan aqiqah juga dapat memperat tali silahturahmi antar sesama sesama anggota keluarga, tetangga dan masyarakat yang ada disekitar kita, dengan kata lain melakukan aqiqah dapat menciptakan lingkungan yang damai. Menurut Kurniawan (2016:212) bahwa situasi dan kondisi aman, tertib serta tentramnya kehidupan masyarakat sebagai salah satu prasyarat terselenggaranya proses pembangunan nasional dalam tercapainya tujuan nasional, ditandai dengan terjaminnya keamanan, ketertiban, dan tegaknya hukum serta terbinanya ketentuan yang mengandung kemampuan dan kekuatan masyarakat dalam menangkal, mencegah dan menanggulangi segala bentuk pelanggaran hukum dan bentuk-bentuk gangguan lainnya yang meresahkan masyarakat. 


\section{Peduli Sosial}

Berdsarkan hasil penelitian dapat sisimpulkan bahwa dalam pelaksanaan adat aqiqah terdapat pembelajaran nilai karakter peduli sosial yang bertujuan untuk senantiasa mengajarkan individu sadar akan kepedulian terhadap sesama lingkungan masyarakat. Membagikan daging aqiqah mengajarkan individu sadar akan kepedulian terhadap sesama manusia.

\section{Tanggung Jawab}

Berdasarkan hasil penelitian dapat disimpulkan bahwa pelaksanaan aqiqah juga mengajarkan sikap tanggung jawab yang sangat penting dimliki setiap orang. Sikap dan perilaku tanggung jawab yang dapat dipelajari melalui pelaksanaan aqiqah ini tercermin dari usaha untuk melakukan aqiqah terhadap anak dan juga saling mengingatkan satu sama lain jika dalam proses aqiqah ada yang kurang atau sudah tidak sesuai. Menurut Kurniawan (2016:218) bahwa sikap tanggung jawab perlu ditumbuhkan di kalangan masyarakat. Sikap ini salah satunya dapat ditumbuhkan dengan cara membangun kemitraan anatara polisi dan masyarakat, misalnya dalam usaha memelihara ketertiban dan meminimalisasi kasus-kasus kejahatan.

\section{PEMBAHASAN}

Berdasarkan hasil penelitian maka dapat dilihat dalam pelaksanaan aqiqah terdapat nilai-nilai pendidikan karakter yang berhubungan dengan sikap dan perilaku. Sebagimana Menurut Kemendiknas (dalam Wibowo 2013) karakter adalah watak, tabiat, akhlak, atau kepribadian seseorang yang terbentuk dari hasil internalisasi berbagai kebajikan (virtues), yang diyakini dan digunakan sebagai landasan untuk cara pandang berpikir, bersikap, dan bertindak.

Pendidikan tidak mungkin bisa dipisahkan dari kebudayaan. Pada hakekatnya pendidikan adalah proses pembudayaan, dengan tujuan agar peserta didik kelak dapat hidup layak dan berguna bagi diri dan bagi kehidupan masyarakatnya. Pendidikan seharusnya berlandaskan pada budaya bangsa, karena budaya sendiri memberikan nilai-nilai positif dalam menghadapi modernisasi. Bangsa yang unggul adalah bangsa yang memiliki kecerdasan budaya dengan ditandai oleh kemampuan mengelola nilainilai kebajikan tradisi. Kecerdasan budaya bukan bermakna mengusung budaya lama untuk diterapkan pada masa kini, melainkan mengelola nilai-nilai budaya lama sebagai aset kebangsaan. Intinya, kurikulum pendidikan harus berbasis dengan budaya bangsa. Menurut Barnouw (dalam Matsumoto 2008 : 6) budaya sebagai sekumpulan sikap, nilai, keyakinan, dan perilaku yang dimiliki bersama oleh sekelompok orang, yang dikomunikasikan dari generasi ke generasi berikutnya lewat bahasa atau beberapa sarana komunikasi lain.

Pendidikan karakter berbasis budaya menegaskan bahwa kebudayaan dimaknai sebagai sesuatu yang diwariskan atau dipelajari, kemudian meneruskan apa yang dipelajari serta mengubahnya menjadi sesuatu yang baru, itulah inti dari proses pendidikan. Apabila demikian adanya, maka tugas pendidikan sebagai misi kebudayaan harus mampu melakukan proses; pertama pewarisan kebudayaan, kedua membantu individu memilih peran sosial dan 
mengajari untuk melakukan peran tersebut, ketiga memadukan beragam identitas individu ke dalam lingkup kebudayaan yang lebih luas, keempat harus menjadi sumber inovasi sosial.

Tahapan tersebut diatas, mencerminkan jalinan hubungan fungsional antara pendidikan dan kebudayaan yang mengandung dua hal utama, yaitu: Pertama, bersifat reflektif, pendidikan merupakan gambaran kebudayaan yang sedang berlangsung. Kedua, bersifat progresif, pendidikan berusaha melakukan pembaharuan, inovasi agar kebudayaan yang ada dapat mencapai kemajuan. Kedua hal di atas, sejalan dengan tugas dan fungsi pendidikan adalah meneruskan atau mewariskan kebudayaan serta mengubah dan mengembangkan kebudayaan tersebut untuk mencapai kemajuan kehidupan manusia. Disini letak pendidikan karakter itu, dimana proses pendidikan merupakan ikhtiar pewarisan nilainilai yang ada kepada setiap individu sekaligus upaya inovatif dan dinamis dalam rangka memperbaharui nilai tersebut ke arah yang lebih maju lagi.

Oleh karena itu, pendidikan karakter merupakan tujuan terakhir dari sebuah proses pendidikan. Karakter adalah buah dari budi nurani yang bersumber pada moral dan moral bersumber pada kesadaran hidup yang berpusat pada alam pikiran. Moral memberikan petunjuk, pertimbangan, dan tuntunan untuk berbuat dengan tanggung jawab sesuai dengan nilai, norma yang dipilih. Jadi, mempelajari karakter tidak lepas dari mempelajari nilai, norma, dan moral.

\section{SIMPULAN}

Berdasarkan hasil penelitian, maka dapat dikemukakan kesimpulan bahwa dalam pelaksanaan adat aqiqah di Gorontalo memiliki nilai-nilai pendidikan karakter di dalamnya seperti, religius, jujur, toleransi, disiplin, mandiri, demokratis, cinta tanah air, bersahabat/komunikatif, cinta damai, peduli sosial, dan tanggung jawab.

\section{DAFTAR PUSTAKA}

Abidin, Yunus. (2012). Pembelajaran Membaca Berbasis Pendidikan Karakter. Bandung: PT Refika Aditama.

Asrori, Ahmad Mar'uf. (1998). Berkhitan dan Aqiqah Upaya Pembentukan Generasi Qur'ani. Surabaya: Al-Miftah.

Botutihe, Medi \& Daulima, Farha. (2003). Tata Cara Adat Gorontalo. Gorontalo: Generasi Penerus.

Daryanto \& Suryati Darmiyatun. (2013). Implementasi Pendidikan Karakter di Sekolah. Yogyakarta: Gava Media.

Kurniawan, Syamsul. (2016). Pendidikan Karakter Konsepsi \& Implementasinya Secara Terpadu di Lingkungan Keluarga, Sekolah, Perguruan Tinggi, dan Masyarakat. Yogyakarta: Ar-Ruzz Media.

Liputo Weni, A. Paramani, H. Harun \& R. Lalu. (2006). Ragam Upacara Tradisional Daerah Gorontalo. Gorontalo.

Matsumoto, David. (2008). Pengantar Psikologi Lintas Budaya.Yogyakarta; Pustaka Pelajar. 
Prayito \& Amti, Erman. (2015). Dasar-dasar Bimbingan dan Konseling. Jakarta: Rineka Cipta.

Purnomo, Sutrisno. (2014). Pendidikan Karakter di Indonesia Antara Asa dan Realita. Jurnal Pendidikan. Volume 2, Nomor 2, Tahun 2014. Diakses pada http $/ /$ media.neliti.com/media/publications/104252-ID-pendidikan-karakter-diindonesia-antara.

Sugiyono. (2016). Metode Penelitian Kuantitaif Kualitatif dan R\&D. Yogyakarta: Alfabeta.

Tohopi, Ridwan. (2012). Budaya Islam Lokal Gorontalo Tradisi Perayaan Isra Mi'Raj. Gorontalo: Sultan Amai Press.

Uno, Hmazah B. (2013). Landasan Pendidikan. Sebuah Pemikiran Komperhensif Landasan Pendidikan Berbasis Karakter di Indonesia. Gorontalo: Ideas Publishing.

Wibowo, Agus. (2013). Manajemen Pendidikan Karakter di Sekolah. Yogyakarta: Pustaka Pelajar.

Yusuf, Juntika Nurihsan. (2011). Landasan Bimbingan dan Konseling. Bandung: PT Remaja Rosdakarya. 